\title{
PERAN DPRD DALAM MEMBANGUN PEMERINTAHAN YANG BAIK DAN BERWIBAWA
}

\author{
Nurochman \\ Dewan Perwakilan Rakyat Daerah Kota Batu \\ Email : nurochman111@gmail.com
}

\begin{abstract}
Abstrak
DPRD Kota Batu berusaha maksimal membangun pemerintahan daerah yang baik dan berwibawa. Standar baik dan kuat ini terletak terwujudnya suatu pemerintahan yang dapat menjalankan perintah peraturan perundang-undangan dengan sebaik-baiknya sesuai dengan kepentingan masyarakat di Kota Batu. Penyelenggaraan pemerinatahan daerah di Kota Batu identik dengan sejumlah pemerintahan daerah di Propinsi lain, yang sama-sama mengandalkan optimalisasi, efektifitas, dan profesionalitas kinerja dewan, sehingga apa yang diperankan oleh DPRD Kota Batu pun menentukan bangunan pemerintahan sekarang dan mendatang. Oleh karena itu, DPRD Kota Batu akan berusaha memaksimalisasikan peran yang sudah digariskan oleh norma yuridis.
\end{abstract}

Kata kunci: dewan, peran, yuridis, kinerja, penyelenggaraan

\begin{abstract}
The Batu City DPRD tries its best to build good and authoritative regional government. This good and strong standard lies in the realization of a government that can best carry out the orders of laws and regulations in accordance with the interests of the people in Batu City. The implementation of regional government in Kota Batu is identical with a number of regional governments in other provinces, which both rely on the optimization, effectiveness and professionalism of the performance of the council, so that what is played by the Batu City DPRD determines the current and future government buildings. Therefore, the Batu City DPRD will try to maximize the role outlined by juridical norms.
\end{abstract}

Keywords: board, role, juridical, performance, administration

\section{PENDAHULUAN}

Tiap manusia mempunyai sifat, watak, dan kehendak sendiri-sendiri. Namun di dalam masyarakat manusia mengadakan hubungan antara yang satu dengan lainnya, mengadakan kerjasama, tolong menolong, Bantu membantu, dan lainnya untuk memperoleh keperluan hidupnya. Keperluan atau kepentingan manusia kadang-kadang baru bisa dipenuhi oleh manusia lainnya Peran manusia lain akan menjadikan terjadinya hubungan sosial yang lebih baik dan saling menguntungkan. ${ }^{1}$

Kepentingan itu setidaknya dapat terbaca dalam pertimbangan UndangUndang Republik Indonesia Nomor 23 Tahun 2014 Tentang Pemerintahan hal. 33 .

${ }^{1}$ CST. Kansil, Pengantar Hukum dan Tata Hukum Indonesia, Djambatan, Jakarta, 2000, 


\section{Jurnal Negara dan $\mathcal{X}$ eadilan \\ p-ISSN 2302-7010 e-ISSN 2721-9801}

Daerah, bahwa penyelenggaraan pemerintahan daerah diarahkan untuk mempercepat terwujudnya kesejahteraan masyarakat melalui peningkatan pelayanan, pemberdayaan, dan peran serta masyarakat, serta peningkatan daya saing daerah dengan memperhatikan prinsip demokrasi, pemerataan, keadilan, dan kekhasan suatu daerah dalam sistem Negara Kesatuan Republik Indonesia; dan bahwa efisiensi dan efektivitas penyelenggaraan pemerintahan daerah perlu ditingkatkan dengan lebih memperhatikan aspek-aspek hubungan antara Pemerintah Pusat dengan daerah dan antardaerah, potensi dan keanekaragaman daerah, serta peluang dan tantangan persaingan global dalam kesatuan sistem penyelenggaraan pemerintahan negara.

Salah satu idealitas otonomi daerah yang diatur norma hukum adalah terwujudnya konstruksi pemerintahan daerah yang baik dan berwibawa (sebagaimana yang dikehendaki norma yuridis). Kuatnya pemerintahan daerah ditandai atau diindikasikan dengan berjalannya peran masing-masing pilar pemerintahan sebagaimana yang digariskan dalam peraturan perundangundangan. Ekspektasi publik terhadap implementasi peran masing-masing pilar ini merupakan harapan normal sebagai implikasi terjadinya perubahan rezim dan sejumlah tatanan yang mengaturnya. ${ }^{2}$ setiap implementasi ini tentu saja dikaitkan dengan norma yuridis sebagai landasan atau pijakan setiap subyek bangsa, termasuk hubungan dan peran para pemangku kekuasaan di lingkungan eksekutif, legislatif, dan yudikatif.

Dari sekian banyak jenis hubungan dan wewenang antara DPRD dengan Kepala Daerah tersebut diatur dalam peraturan perundang-undangan, sehingga terlihat bahwa Kepala Daerah bukan merupakan penguasa tunggal di daerah, karena penyelenggara pemerintah daerah adalah Kepala Daerah dan DPRD, hal ini diharapkan agar tercipta iklim demokrasi dalam penyelenggaraan pemerintahan daerah, kemudian terjadi check and balance, gambaran tersebut dapat diklarifikasikan menjadi tiga jenis hubungan, yaitu hubungan kemitraan (partnership), hubungan pengawasan (controlling), dan hubungan anggaran (budgeting), seperti halnya hubungan antara DPR dengan Presiden pada Pemerintah Pusat. ${ }^{3}$

Norma hukum dibutuhkan untuk mengatur hubungan kehidupan bermasyarakat dan bernegara. Dalam hubungan yang dibangun oleh setiap orang atau pihak, ditentukan oleh norma yang mengaturnya. Norma yang mengatur ini menjadi pijakan kepastian bersikap dan berperilakunya.

\section{METODE PENELITIAN}

Dengan menggunakan pemikiran Bambang Sunggono ${ }^{4}$, penelitian yang peneliti lakukan ini dapat disebut sebagai penelitian kasus. artinya, penelitian ini pada umumnya bertujuan untuk mempelajari secara mendalam terhadap suatu individu, kelompok, instititusi atau masyarakat tertentu, tentang latar belakang, keadaan, kondisi, faktor-faktor atau interaksi-interaksi sosial yang terjadi di

\footnotetext{
${ }^{2}$ Abdillah Hamdani, Hukum dan Pemerintahan Daerah, Supapipres, Yogyakarta, 2015, hal.4.

3I Gde Panca Astawa, Problematika Hukum Otonomi Daerah di Indonesia, Alumni, Bandung, 2008, hal. 112

${ }^{4}$ Bambang Sunggono, Metode Penelitian Hukum, Rajagrafindo Persada, Jakarta, 1997, hal. 31
} 


\section{Jurnal Negara dan Zeadilan \\ p-ISSN 2302-7010 e-ISSN 2721-9801}

dalamnya. Sedangkan problem yang ingin diketahui dan dipahami adalah tentang implementasi yang dilakukan DPRD Kota Batu dalam membangun pemerintahan yang bersih dan berwibawa dan hambatan dan upaya apa saja yang dilakukan DPRD Kota Batu dalam membangun pemerintahan yang bersih dan berwibawa.

Selain itu, penelitian tersebut disebut pula sebagai yuridis empirik, yakni penelitian tentang implementasi atau penerapan norma-norma yuridis atau normanorma hukum di masyarakat. Pendekatan yang digunakan dalam penelitian ini adalah pendekatan sosiologis, kasuistis, dan peraturan perundang-undangan.

\section{PEMBAHASAN}

Dalam kapasitasnya sebagai penyelenggara Pemerintahan Daerah, DPRD Kota Batu mempunyai kedudukan yang sama dengan Pemerintah Daerah (walikota) dalam membangun dan mengusahakan dukungan dalam penetapan kebijakan Pemerintah Daerah yang dapat menampung dan menyalurkan aspirasi masyarakat, sehingga kebijakan dimaksud dapat diterima oleh masyarakat luas.

Upaya peningkatan peran dan fungsi DPRD Kota Batu tersebut, tentunya sejalan dengan semakin besarnya tuntutan masyarakat terhadap kinerja lembaga legislatif, yang merupakan pilar utama dalam mewujudkan kedaulatan rakyat. DPRD dituntut untuk lebih aspiratif, proaktif dan professional dalam menjalankan tugas dan kewajibannya.

DPRD Kota Batu juga diharapkan menjadi lembaga penyeimbang untuk mencegah penyelenggaraan Pemerintah Daerah yang otoriter. Hal ini tentunya membuat tugas dan tanggung jawab DPRD Kota Batu semakin berat, khususnya dalam kaitannya dengan penyelenggaraan atau pengiomplementasian pemerintahan yang baik dan berwibawa.

Dapat kita kaji, bahwa bergulirnya era globalisasi dan reformasi politik telah mendorong terjadinya berbagai perubahan tatanan kehidupan bermasyarakat, berbangsa dan bernegara. Secara spesifik dalam konteks penyelenggaraan pemerintahan daerah, pelaksanaan reformasi telah melahirkan berbagai dinamika politik lokal. Terjadinya euphoria yang mendominasi kehidupan dan perilaku masyarakat pada kurun waktu terakhir merupakan anti klimaks dari berbagai fenomena sosial yang selama ini tidak memperoleh solusi secara baik. ${ }^{5}$ Disinilah kemudian masing-masing Lembaga yang membawa bendera kepentingan rakyat, termasuk DPRD di Kota Batu berusaha menunjukkan kalau dirinya bisa atau kapabel dalam memberikan yang terbaik, khususnya bagi masyarakat dan pemerintahan Kota Batu.

Salah satu lembaga strategis dalam pemerintahan, selain eksekutif adalah legislatif. Secara yuridis memang sudah digariskan mengenai kewenangan dan tugas yang harus dijalankan oleh legislatif, tetapi ketika hal itu dikorelasikan dengan realitas sosial-empirik, maka eksistensi legislatif kembali digugat atau dipertanyakan, mengingat antara idealitas normatif dalam peraturan perundangundangan seringkali tidak sejalan dengan praktik-praktik politiknya. Faktor-faktor perubahan politik juga berpengaruh besar terhadap peran atau perilaku yang dibangun oleh praktisi politik itu, yakni Dewan Perwakilan Rakyat Daerah.

${ }^{5}$ Ondo Riyani dan Sadu Wasistiono, 2003, Etika Hubungan Legislatif - Eksekutif

Dalam Pelaksanaan Otonomi Daerah, Fokus Media, Bandung, 2003, hal. 111 


\section{Zurnal Negara dan $\mathcal{X}$ eadilan \\ p-ISSN 2302-7010 e-ISSN 2721-9801}

Seorang pakar di bidang ilmu politik Karl Lowenstein menyatakan "hakekat politik merupakan perjuangan untuk memperoleh kekuasaan, teknik menjalankan kekuasaan, dan mengontrol kekuasaan". 6

Salah satu subyek demokrasi yang sangat strategis dalam penyelenggarakan kehidupan pemerintahan dan demokrasi kita adalah DPRD. Di zaman Orba, unsur legislatif ini pernah menjadi kekuatan yang turut menciptakan distorsi demokrasi, sehingga demokrasi layak disebut gagal menjadi kekuatan moral politik bernegara yang ideal. Demokrasinya tetap ideal, namun di era ini hanya dalam wacana, sedangkan dalam realita terbatas dijadikan simbol-simbol penyelenggaraan kekuasaan.

Di era reformasi ini, secara yuridis DPRD, termasuk tentu saja DPRD Kota Batu, telah diberikan kedudukan yang lebih strategis baik dalam tugas, fungsi, dan kewajibannya. Strategisnya tanggungjawab ini wajar seiring dengan besarnya hak-hak yang diberikan oleh negara kepadanya.

Dewan Perwakilan Rakyat Daerah (DPRD) sebagai lembaga perwakilan rakyat, secara konseptual memegang tiga peran.Pertama, sebagai agen perumus agenda bagi masyarakat yang diwakilinya.Kedua, DPRD berperan sebagai lembaga yang mengemban misi pengelolaan konflik dalam masyarakatnya.Ketiga, DPRD adalah pengemban peran integratif dalam masyarakatnya.Peran perwakilan rakyat yang diemban oleh DPRD bisa dimaknai sebagai peran keperantaraan.DPRD bukan hanya menjadi perantara yang menjembatani pemerintah (eksekutif) dengan rakyatnya, namun juga menjembatani ketegangan dari berbagai segmen dalam masyarakat yang saling memperjuangkan kepentingannya. Dalam praktik kehidupan demokrasi DPRD sebagai lembaga legislatif memiliki posisi sentral yang dipandang terpercaya untuk membawakan aspirasi masyarakat di dalam pemerintahan. Hal ini didasarkan pada suatu pandangan bahwa badan legislatif yang dapat mewakili rakyat dan memiliki kompetensi untuk memenuhi kehendak rakyat. DPRD yang memegang peranan penting dalam sistem demokrasi paling berperan dalam proses kehidupan demokratisasi di daerah. Walaupun dalam kenyataannya DPRD masih belum sepenuhnya menjalankan fungsinya dengan baik, bahkan dalam prakteknya DPRD sering mengaburkan makna demokrasi itu sendiri. ${ }^{7}$

Selaras dengan hal tersebut di atas, lembaga perwakilan rakyat merupakan unsur yang sangat penting di samping unsur-unsur lainnya seperti, sistem pemilihan, persamaan di depan hukum, kebebasan berserikat dan sebagainya. Setiap sistem demokrasi selalu didasarkan pada ide bahwa warga negara seharusnya terlihat dalam hal tertentu di bidang pembuatan keputusan-keputusan politik, baik secara langsung maupun melalui wakil pilihan mereka di lembaga perwakilan. ${ }^{8}$

Di awal menempati posisi, DPRD sudah diingatkan secara moral mengenai tanggungjawabnya dalam menegakkan demokrasi dan membangun pemerintahan yang bersih. Hal ini dapat terbaca dalam pasal 369 Undang-undang

${ }^{6}$ Misbahul Munir,. Pemilihan Umum dan Ijtihad Politik Perempuan, Surabaya, Visipress, 2004, hal. 25.

7 Jhony Fredy Hahury, Fungsi DPRD Dalam Mewujudkan Good Governance, Jurnal Fokus, Jilid 12, Nomor 2, Maret 2014, hal. 265,

8 Tower Lyiman Sarjen, Idelologi Politik Kontemporer, Gramedia, Jakarta, 2000, hal. 1 


\section{Jurnal Negara dan Zeadilan \\ p-ISSN 2302-7010 e-ISSN 2721-9801}

Republik Indonesia nomor 17 tahun 2014 Majelis Permusyawaratan Rakyat, Dewan Perwakilan Rakyat,Dewan Perwakilan Daerah, Dan Dewan Perwakilan Rakyat Daerah yang berbunyi: "Demi Allah (Tuhan) saya bersumpah/berjanji:bahwa saya akan memenuhi kewajiban saya sebagai anggota (ketua/wakil ketua) Dewan Perwakilan Rakyat Kabupaten/Kota dengan sebaikbaiknya dan seadil-adilnya;bahwa saya akan memegang teguh Pancasila dan menegakkan Undang-Undang Dasar Negara Republik Indonesia Tahun 1945 serta peraturan perundang-undangan;bahwa saya akan menegakkan kehidupan demokrasi serta berbakti kepada bangsa dan negara;bahwa saya akan memperjuangkan aspirasi rakyat yang saya wakili untuk mewujudkan tujuan nasional demi kepentingan bangsa dan negara kesatuan Republik Indonesia. ${ }^{\prime 9}$

Sumpah tersebut merupakan suatu perikatan moral politik kenegaraan, bahwa DPRD di daerah manapun, termasuk di Kota Batu punya tanggungjawab besar dalam membangun demokrasi dan mewujudkan pemerintahan yang bersih (clean government). Rakyat yang diwakilinya, karena telah memilihnya dalam Pemilu, idealnya merupakan representasi perjuanganya sebagai unsur penyelenggaraan kekuasaan di daerah. Sedangkan kekuasaan di daerah inilah yang menjadi cermin penyelengaraan kehidupan kenegaraan.

Hal itu makin tegas dalam terbaca Pasal 343 UU Nomor 27 tahun 2009, bahwa DPRD Kabupaten/Kota mempunyai fungsi: a) legislasi; b) anggaran; dan, c) pengawasan. Fungsi ini jelas tidak fungsi main-main, karena menyangkut masalah besar bangsa atau rakyat di daerah, seperti produk peraturan perundangundangan, keuangan daerah, dan kontrol terhadap jalannya kekuasaan yang dilakukan eksekutif.

Pengawasan yang menjadi fungsi legislatif tersebut menjadi strategis di saat rakyat sedang menuntut suatu model pemerintahan yang bersih. Bobroknya pemerintahan di daerah selama ini dibutuhkan pemberdayaan lebih maksimal atas fungsi pengawasan yang dilakukan oleh DPRD. Kasus di Kota Batu, dimana pernah tersangkutnya pimpinan daerah dalam perkara hukum dengan tuduhan melakukan penyalahgunaan kekuasaan seperti tindak pidana korupsim secara langsung atau tidak langsung telah mencoreng kewibawaan pemerinatahn Kota Batu, sehingga membuat komunitas DPRD merasa dituntut supaya kasus demikian tidak akan terulang di masa mendatang.

Oleh karena itu, Implementasi peran DPRD Kota Batu terjabarkan pula dalam tugas dan wewenang DPRD sebagaimana diatur dalam Pasal 366 Undangundang Republik Indonesia nomor 17 tahun 2014 tentang Susunan dan Kedudukan Majelis Permusyawaratan Rakyat, Dewan Perwakilan Rakyat, Dewan Perwakilan Daerah, dan Dewan Perwakilan Rakyat Daerah. ${ }^{10}$

Dalam Pasal 18A UUD 1945, diamanatkan hubungan wewenang antara pemerintah pusat dan pemerintahan daerah propinsi, kabupaten , dan kota, atau antara propinsi, kabupaten serta kota, diatur dengan undang-undang dengan memperhatikan kekhususan dan keragaman daerah. Disamping itu, hubungan keuangan, pelayanan umum, pemanfaatan sumber daya alam, serta sumber daya

${ }^{9}$ Undang-undang Republik Indonesia nomor 27 tahun 2009 tentang Majelis Permusyawaratan Rakyat, Dewan Perwakilan Rakyat, Dewan Perwakilan Daerah, dan Dewan Perwakilan Rakyat Daerah

${ }^{10}$ Tidak termasuk yang diamandemen dalam UU yang baru 


\section{Hurnal Negara dan $\mathcal{X}$ eadilan \\ p-ISSN 2302-7010 e-ISSN 2721-9801}

lainya antara pemerintah pemerintah pusat dan pemerintah daerah diatur dan dilaksanakan secara adil dan selaras berdasarkan undang-undang. Perubahan terhadap Pasal 18 tersebut dapat dilihat sejumlah paradigma penyelenggaraan pemerintahan daerah, paradigma yang dimaksud adalah $:{ }^{11}$

1) Pemerintahan daerah disusun dan dijalankan berdasarkan otonomi dan tugas pembantuan (belaka). Dimasa depan tidak ada lagi pemerintahan dekonsentrasi dalam pemerintahan daerah

2) Pemerintahan daerah disusun dan dijalankan atas dasar otonomi seluas-luasnya. Semua fungsi pemeritahaan di bidang administrasi negara (administratief regelen en bestur) dijalankan oleh pemerintah daerah, kecuali yang ditentukan oleh pemeriintah pusat;

3) Pemerintahan daerah disusun dan dijalankan atas dasar keragaman daerah. Urusan rumah tangga tidak perlu seragam. Peerbedaan harus dimungkinkan baik atas dasar kultural, sosial, ekonomi, geografi, dan lain sebagainya;

4) Pemerintahan daerah disusun dan dijalankan dengan mengakui dan menghormati kesatuan masyarakat hukum adat (adatrechts gemeenschap) dan berbagai hak tradisionalnya. Satuan pemerintah asli dan hakhak masyarakat asli atas bumi, air, dan lain-lain wajib dihormati untuk sebesar-besarnya kemakmuran dan kesejahteraan rakyat setempat.

5) Pemerintahan daerah dapat disusun dan dijalankan berdasarkan sifat atau keadaan khusus tertentu baik atas kedudukan (seperti Ibi kota Negara), kesejarahan (seperti D.I. Yogyakarta), atau karena keadaan sosial kultural (seperti D.I. Aceh dan Papua)

6) Anggota DPRD dipilih langsung dalam suatu pemilihan umum. Dimasa depan tidak ada lagi anggota DPRD (begitu juga anggota DPR ) yang diangkat.

7) Hubungan Pusat dan Daerah dilaksanakan secara selaras dan adil.

Lembaga legislatif, eksekutif, dan yudikatif yang seharusnya dapat membenahi dirinya menjadi pengawal reformasi malah menimbulkan persoalan baru yang saling berhadapan. Begitu juga masih kuatnya asumsi negatif masyarakat terhadap peran eksekutif, stigmatisasi atas legislatif sebagai lembaga yang tidak berfungsi terus terjadi, termasuk pencitraan terhadap kemandulan peran yudikatif. Gejala seperti itu pada gilirannya dapat mengaburkan proses penataan kedaerahan secara baik dan konstitusional. ${ }^{12}$

Deskripsi secara umum tentang wajah pemerintahan di Indonesia, termasuk pemerintahan daerah, merupakan tantangan yang menguji atau memngesaminasi DPRD Kota Batu untuk menyelenggarakan pemerinatahan yang kuat dan berwibawa dengan tetap diselaraskan dengan koridor norma-norma yuridis.

Secara yuridis sudah jelas ditentukan, bahwa dalam menyelenggarakan pemerintahan di daerah seperti di Kota Batu, diperlukan perangkat-perangkat dan lembaga-lembaga untuk menyelenggarakan jalannya pemerintahan di daerah sehari-hari. Sebagaimana hanya di pusat negara, perangkat-perangkat dan

${ }^{11}$ Bagir Manan, Menyongsong Fajar Otonomi Daerah. Pusat Studi Hukum (PSH), Fakultas Hukum UII Yogyakarta, 2001. hal 229.

${ }^{12}$ Abdul Hakiem, Nukman, 2003. Membangun Sistem Politik yang Sehat, Pikiran

Rakyat, 23 September 2003, diakses 15 Januari 2018 


\section{Jurnal Negara dan Zeadilan \\ p-ISSN 2302-7010 e-ISSN 2721-9801}

lembaga-lembaga daerah biasanya merupakan refleks dari sistem yang ada di pusat negara. Untuk memenuhi fungsi perwakilan dalam menjalankan kekuasaan legislative daerah sebagaimana di pusat negara di daerah dibentuk pula Lembaga Perwakilan Rakyat, dan lembaga ini biasa dikenal atau dinamakan Dewan Perwakilan Rakyat Daerah. Dewan Perwakilan Daerah adalah lembaga perwakilan rakyat daerah sebagai unsur penyelenggaraan pemerintahan daerah.

Dalam Pasal 364 Undang-Undang Nomor 17 tahun 2014 tentang Majelis Permusyawaratan Rakyat, Dewan Perwakilan Rakyat, Dewan Perwakilan Daerah, Dan Dewan Perwakilan Rakyat Daerah disebutkan, bahwa DPRD kabupaten/kota merupakan lembaga perwakilan rakyat daerah yang berkedudukan sebagai unsur penyelenggara pemerintahan daerah kabupaten/kota ${ }^{13}$

Penyelenggaraan pemerintahan dalam suatu negara tidak hanya terdapat di pusat pemerintahan saja. Pemerintahan pusat memberikan wewenangnya kepada pemerintah daerah untuk menyelenggarakan pemerintahannya sendiri, dan di Indonesia yang dimaksud dengan pemerintahan daerah adalah penyelenggaraan urusan pemerintahan oleh pemerintah daerah dan DPRD menurut asas otonomi dan tugas pembantuan dengan prinsip otonomi yang seluas-luasnya dalam sistem dan prinsip Negara Kesatuan Republik Indonesia Tahun 1945.

Secara teoritis sudah jelas, bahwa dalam penyelenggaraan pemerintahan di daerah, dilaksanakandengan asas desentralisasi, yaitu penyerahan wewenang pemerintahan oleh Pemerintah kepada daerah otonomi untuk mengatur dan mengurus urusan pemerintahan dalam system Negara Kesatuan Republik Indonesia. Di samping itu juga melaksanakan dekonsentrasi, yaitu pelimpahan wewenang pemerintahan oleh Pemerintah kepada Gubernur sebagai wakil pemerintah dan/atau kepada instansi vertikal, dan serta melaksanakan Tugas Pembantuan, yaitu penugasan dari pemerintahan kepada daerah dan/atau desa dari pemerintahan propinsi kepada kabupaten/kota kepada desa untuk melaksanakan tugas tertentu.

Kalau berpijak pada alur itu, maka DPRD Kota Batu merupakan salah satu pilar penting dalam pemerintahan daerah. Pemerintahan daerah akan menjadi pemerintahan yang kuat, bersih, dan berwibawa, adalah tidak lepas dari besar kecilnya peran yang dijalankan oleh DPRD Kota Batu. Lembaga parlemen atau DPRD Kota Batu itu adalah lembaga politik, dan karena itu pertama-tama haruslah dipahami sebagai lembaga politik, karena di lembaga ini berkumpul perwakilan dari kekuatan politik atau Parpol di masyarakat.

Sifatnya sebagai lembaga politik itu tercermin dalam fungsinya untuk mengawasi jalannya pemerintahan, sedangkan fungsi legislasi lebih berkaitan dengan sifat-sifat teknis yang banyak membutuhkan prasyarat-prasyarat dan dukungan-dukungan yang teknis pula. Mengenai fungsi di bidang anggaran, DPRD berperan dalam penyusunan Rancangan Anggaran Pendapatan dan Belanja Daerah (RAPBD), termasuk RAPBD Kota Batu. Disinilah salah satu eksaminasi strategis yang ditunjukkan DPRD Kota Batu dalam upaya membangun pemerintahan yang baik dan berwibawa. Mencermati dan menghitung dengan cermat identik dengan membangun belanja kepentingan pemerintahan dalam melayani kepentingan rakyat atau masyarakat Kota Batu.

${ }^{13}$ Tidak termasuk yang diamandemen dari Undang-Undang Nomor 17 tahun 2014 tentang Majelis Permusyawaratan Rakyat, Dewan Perwakilan Rakyat, Dewan Perwakilan Daerah, Dan Dewan Perwakilan Rakyat Daerah 


\section{Hurnal Negara dan $\mathcal{X}$ eadilan \\ p-ISSN 2302-7010 e-ISSN 2721-9801}

Lembaga legislatif sebagai lembaga perwakilan dalam bertindak atas nama kepentingan rakyat yang diwakili sebagai pencerminan demokrasi, agar dapat berjalan, lembaga legislatif memiliki beberapa macam fungsi. Berjalannya fungsi lembaga perwakilan rakyat akan dapat mencerminkan derajat demokrasi. Pada umumnya fungsi perwakilan dibedakan menjadi empat macam fungsi, yaitu (1) fungsi penganggaran, (2) fungsi perundangan, (3) fungsi pengawasan, dan (4) fungsi menampung dan menyalurkan aspirasi rakyat (Widodo, 2001:106). DPRD harus melaksanakan fungsinya dengan baik guna mewujudkan pemerintahan yang baik dan bersih yaitu dengan terselenggaranya good governance yang merupakan prasyarat utama mewujudkan aspirasi masyarakat mencapai tujuan dan citacita bangsa dan negara. Supaya pelaksanaan fungsi DPRD dapat terwujud maka pemerintahan dilaksanakan dengan mengedepankan prinsip demokrasi dan prinsipprinsip good governance. DPRD merupakan lembaga legislatif yang para anggotanya terpilih melalui mekanisme Pemilihan Umum. Keberadaannya (DPRD) sangat penting dan strategis dalam melaksanakan perannya guna mewujudkan pemerintahan yang baik dan bersih (good and clean governance) dalam menjalankan fungsinya perlu mengedepankan komitmen moral dan profesionalitas. Komitmen menjadi penting sebagai upaya untuk mewujudkan DPRD yang produktif, terpercaya dan berwibawa. ${ }^{14}$

Dalam ranah idealitas, DPRD, termasuk DPRD Kota Batu, sebagai lembaga legislatif yang kedudukannya sebagai wakil rakyat tidak mungkin melepaskan dirinya dari kehidupan rakyat yang diwakilinya. Oleh karena itu secara material mempunyai kewajiban untuk memberikan pengabdian terbaiknya kepada rakyat atau publik yang diwakilinya.

Jika berpijak pada paparan itu, DPRD Kota Batu sebagai wakil rakyat dalam tindakan atau perbuatan harus menyesuaikan dengan norma-norma yang dianut dan berlaku dalam kebudayaan rakyat yang diwakilinya. Kalau hal ini diikuti atau dipatuhi, DPRD tidak akan melakukan perbuatan yang tidak terpuji, menguntungkan pribadi dan membebani anggaran rakyat untuk kepentingan diri, keluarga, dan kelompoknya.

Kepatuhan pada kepentingan itu bermaknakan, bahwa DPRD juga harus memahami etika pemerintahan supaya dapat mengurangi tindakan-tindakan yang tercela, tidak terpuji dan merugikan masyarakat. Etika pemerintahan ini diantaranya berpijak atau menggunakan tolok ukur diimplementasikan tidaknya kode etik.

Kode etik untuk para anggota DPRD merupakan salah satu pedoman berperilaku baginya untuk dapat dijadikan panduan dalam pelaksanaan peran dan fungsinya, sehingga DPRD benar-benar memahami, bahwa kewenangan yang besar atau fundamentalnya juga disertai dengan tanggung jawab yang besar pula.

Kalau mencermati tuntutan tersebut, maka sosok ideal DPRD Kota Batu yang ditentukan melalui peran-perannya itu dapat diidentikkan bahwa di pundak DPRD Kota Batu terkandung kewajiban memperjuangkanatau mengusahakan secara maksimal tentang terbentuknya pemerintahan kota Batu yang baik dan berwibawa.

Implementasi yang dilakukan DPRD Kota Batu dalam membangun pemerintahan yang baik dan berwibawa adalah berpijak pada norma yuridis yang

\footnotetext{
${ }^{14}$ Jhony Fredy Hahury, op.cit. hal. 265-266.
} 


\section{$\mathcal{H}$ urnal Negara dan Keadilan \\ p-ISSN 2302-7010 e-ISSN 2721-9801}

mengaturnya yang berkaitan dengan peran yang harus dilakukannya, baik dalam hubungannya dengan masyarakat atau eksekutif.

Norma yuridis yang menggarikan tentang peran DPRD Kota Batu yang diantaranya berkenaan dengan fungsi legislatif, anggaran, dan pengawasan. Dalam peran-peran inilah DPRD Kota Batu berusaha maksimal membangun pemerintahan daerah yang baik dan kuat. Standar baik dan kuat ini terletak terwujudnya suatu pemerintahan yang dapat menjalankan perintah peraturan perundang-undangan dengan sebaik-baiknya sesuai dengan kepentingan masyarakat di Kota Batu. Peran yang dilakukan DPRD Kota Batu tidak akan lepas dari koridor norma yuridis, kecuali jika mereka berani berhadapan dengan jeratan pertanggungjawaban hukum.

Penyelenggaraan pemerinatahan daerah di Kota Batu identic dengan sejumlah pemerintahan daerah di Propinsi lain, yang sama-sama mengandalkan optimalisasi, efektifitas, dan profesionalitas kinerja dewan, sehingga apa yang diperankan oleh DPRD Kota Batu pun menentukan bangunan pemerintahan sekarang dan mendatang.

Oleh karena itu, DPRD Kota Batu akan berusaha memaksimalisasikan peran yang sudah digariskan oleh norma yuridis/ disinilah yang menjadi kunci keberhasilan tidaknya implementasi pran DPRD Kota Batu dalam berusaha membangun pemerintahan daerah yang baik dan berwibawa,

\section{PENUTUP}

Implementasi yang dilakukan DPRD Kota Batu dalam membangun pemerintahan yang baik dan berwibawa adalah berpijak pada norma yuridis yang mengaturnya yang berkaitan dengan peran yang harus dilakukannya, baik dalam hubungannya dengan masyarakat atau eksekutif. Norma yuridis yang menggarikan tentang peran DPRD Kota Batu yang diantaranya berkenaan dengan fungsi legislatif, anggaran, dan pengawasan. Dalam peran-peran inilah DPRD Kota Batu berusaha maksimal membangun pemerintahan daerah yang baik dan berwibawa. Standar baik dan kuat ini terletak terwujudnya suatu pemerintahan yang dapat menjalankan perintah peraturan perundang-undangan dengan sebaikbaiknya sesuai dengan kepentingan masyarakat di Kota Batu. Penyelenggaraan pemerinatahan daerah di Kota Batu identic dengan sejumlah pemerintahan daerah di Propinsi lain, yang sama-sama mengandalkan optimalisasi, efektifitas, dan profesionalitas kinerja dewan, sehingga apa yang diperankan oleh DPRD Kota Batu pun menentukan bangunan pemerintahan sekarang dan mendatang. Oleh karena itu, DPRD Kota Batu akan berusaha memaksimalisasikan peran yang sudah digariskan oleh norma yuridis.

\section{Buku}

\section{DAFTAR PUSTAKA}

Abdillah Hamdani, Hukum dan Pemerintahan Daerah, Supapipres, Yogyakarta, 2015

Bambang Sunggono, Metode Penelitian Hukum, Rajagrafindo Persada, Jakarta, 1997.

Bagir Manan, Menyongsong Fajar Otonomi Daerah. Pusat Studi Hukum (PSH), Fakultas Hukum UII Yogyakarta, 2001 


\section{Jurnal Negara dan $\mathcal{X}$ eadilan \\ p-ISSN 2302-7010 e-ISSN 2721-9801}

CST. Kansil, Pengantar Hukum dan Tata Hukum Indonesia, Djambatan, Jakarta, 2000.

I Gde Panca Astawa, Problematika Hukum Otonomi Daerah di Indonesia, Alumni, Bandung, 2008.

Misbahul Munir,. Pemilihan Umum dan Ijtihad Politik Perempuan, Surabaya,Visipress, 2004.

Ondo Riyani dan Sadu Wasistiono, 2003, Etika Hubungan Legislatif - Eksekutif Dalam Pelaksanaan Otonomi Daerah, Fokus Media, Bandung, 2003. Tower Lyiman Sarjen, Idelologi Politik Kontemporer, Gramedia, Jakarta, 2000

\section{Jurnal}

Jhony Fredy Hahury, Fungsi DPRD Dalam Mewujudkan Good Governance, Jurnal Fokus, Jilid 12, Nomor 2, Maret 2014.

\section{Peraturan Perundang-undangan}

Undang-undang Republik Indonesia nomor 27 tahun 2009 tentang Majelis Permusyawaratan Rakyat, Dewan Perwakilan Rakyat, Dewan Perwakilan Daerah, dan Dewan Perwakilan Rakyat Daerah

Undang-Undang Nomor 17 tahun 2014 tentang Majelis Permusyawaratan Rakyat, Dewan Perwakilan Rakyat, Dewan Perwakilan Daerah, Dan Dewan Perwakilan Rakyat Daerah

\section{Internet}

Abdul Hakiem, Nukman, 2003. Membangun Sistem Politik yang Sehat, Pikiran Rakyat, 23 September 2003, diakses 15 Januari 2018 